\title{
Axillary Bud Development of Poinsettia 'Eckespoint Lilo' and 'Eckespoint Red Sails' (Euphorbia pulcherrima Willd.) Is Inhibited by High Temperatures
}

\author{
James E. Faust ${ }^{1}$ and Royal D. Heins ${ }^{2}$ \\ Department of Horticulture, Michigan State University, East Lansing, MI 48824
}

Additional index words. apical dominance, branching, pinching

\begin{abstract}
The effect of temperature on axillary bud and lateral shoot development of poinsettia (Euphorbia pulcherrima Willd.) 'Eckespoint Lilo' and 'Eckespoint Red Sails' was examined. Rooted 'Eckespoint Lilo' cuttings were transplanted and placed into growth chambers maintained at $21,24,27$, or $30{ }^{\circ} \mathrm{C}$ for 2 weeks before apex removal. The percentage of nodes developing lateral shoots after apex removal was $68 \%, 69 \%, 73 \%$, or $76 \%$ at $21,24,27$, or $30{ }^{\circ} \mathrm{C}$, respectively. Cuttings were removed from the lateral shoots, rooted, and placed into a $21^{\circ} \mathrm{C}$ greenhouse, and the apices were removed. The percentage of nodes developing into lateral shoots on cuttings taken from plants held at $21,24,27$, and $30{ }^{\circ} \mathrm{C}$ were $74 \%$, $65 \%, 66 \%$, and $21 \%$, respectively. Of the cuttings in the $30{ }^{\circ} \mathrm{C}$ treatment, $83 \%$ of the nodes not producing a lateral shoot had poorly developed axillary buds or no visible axillary bud development. Visual rating of axillary bud viability decreased from $100 \%$ to $0 \%$ when 'Eckespoint Red Sails' plants were transferred from a $21{ }^{\circ} \mathrm{C}$ greenhouse to a greenhouse maintained at $27^{\circ} \mathrm{C}$ night temperature and $30{ }^{\circ} \mathrm{C}$ for 3 hours followed by $33{ }^{\circ} \mathrm{C}$ for 10 hours and $30^{\circ} \mathrm{C}$ for 3 hours during the 16-hour day. Transfer from the high-temperature greenhouse to a $21{ }^{\circ} \mathrm{C}$ greenhouse increased axillary bud viability from $0 \%$ to $95 \%$. Axillary buds of leaves not yet unfolded were sensitive to high temperatures, whereas those of unfolded leaves (i.e., fully developed correlatively inhibited buds) were not. Sixteen consecutive days in the high-temperature treatment were required for axillary bud development of 'Eckespoint Red Sails' to be inhibited.
\end{abstract}

The commercial success of poinsettia is due, at least in part, to the development of the 'Annette Hegg' family of cultivars that branch freely on removal of the shoot apex (pinching) (Ecke et al., 1990). However, certain cultivars, including 'Eckespoint Lilo' (Lilo) and 'Eckespoint Red Sails' (Red Sails), occasionally branch poorly after pinching; some plants develop no lateral shoots after pinching.

Poorly branched poinsettias can cause significant economic losses. Poinsettias are vegetatively propagated from shoot-tip cuttings; therefore, poorly branched stock plants do not produce the projected number of cuttings. Market specifications for the finished product require five or more laterals on pinched plants at flower. Plants that produce fewer than five flowering laterals after pinching are sold at a reduced price; those that produce fewer than three are discarded.

Poinsettia cultivars differ in their capacity to branch after pinching, and cultivars are often referred to as free-branching or restricted-branching. Reciprocal grafting of free-branching and restricted-branching plants suggests that the branching factor is graft-transmissible (Stimart, 1983). A virus has been proposed as the branching factor, since poinsettias regenerated following heat treatment (Dole and Wilkins, 1994) or suspension culture (Preil, 1994; Preil and Engelhart, 1982) do not have the free-branching characteristic; however, the specific factor has not been identified (Dole and Wilkins, 1991, 1992; Dole et al., 1993).

The cause of inconsistent branching in the normally freebranching cultivars Lilo and Red Sails is not known, although the

Received for publication 26 May 1995. Accepted for publication 18 Mar. 1996. This research was supported in part by the Paul Ecke Poinsettia Ranch.

${ }^{1}$ Former graduate student. Current address: Univ. of Tennessee, Dept. of Ornamental Horticulture and Landscape Design, Knoxville, TN 37901-1071.

${ }^{2}$ Professor. problem may be temperature related since poor branching occurs more frequently in the southern United States (personal communication, David Hartley). High temperature has been linked to the inhibition of axillary bud development of chrysanthemum (Faust and Heins, 1992; Schoelhorn et al., 1995) and peach (Boonprakob et al., 1993). Visual observations indicate that axillary buds often fail to develop properly in the leaf axils of poorly branching cultivars (Faust and Heins, 1993). Poor axillary bud development ranges from the absence of any differentiation (i.e., a "blind" leaf axil) to the appearance of undifferentiated tissue that, with time, develops a necrotic surface.

To our knowledge, no data are available to determine if poor branching of Lilo and Red Sails poinsettias is a result of poor axillary bud development or correlative inhibition by the apex or if axillary bud development is predetermined by factors occurring during stock plant production, propagation, or finished plant production. Our objective was to test the hypothesis that high temperature inhibits axillary bud development in poinsettia, resulting in poor lateral shoot development, and, if the hypothesis is true when during plant development is exposure to high temperature effective.

\section{Materials and Methods}

Experiment 1 . Fifty rooted Lilo cuttings were received from a commercial grower (Paul Ecke Poinsettia Ranch, Encinatas, Calif.), transplanted into pots $15 \mathrm{~cm}$ in diameter $\left(1200 \mathrm{~cm}^{3}\right)$, and placed in a greenhouse that was maintained at $21 \pm 1{ }^{\circ} \mathrm{C}$. Shade cloth reducing photosynthetic photon flux (PPF) by $50 \%$ was placed above the plants for 1 week.

After 2 weeks, 25 plants were placed in each of five growth chambers (model E-15; Conviron, Asheville, N.C.) maintained at $21,24,27,30$, or $33 \pm 1{ }^{\circ} \mathrm{C}$. Plants were exposed to a PPF of 600 $\pm 30 \mu \mathrm{mol} \cdot \mathrm{m}^{-2} \cdot \mathrm{s}^{-1}$ from fluorescent and incandescent lamps for 16 


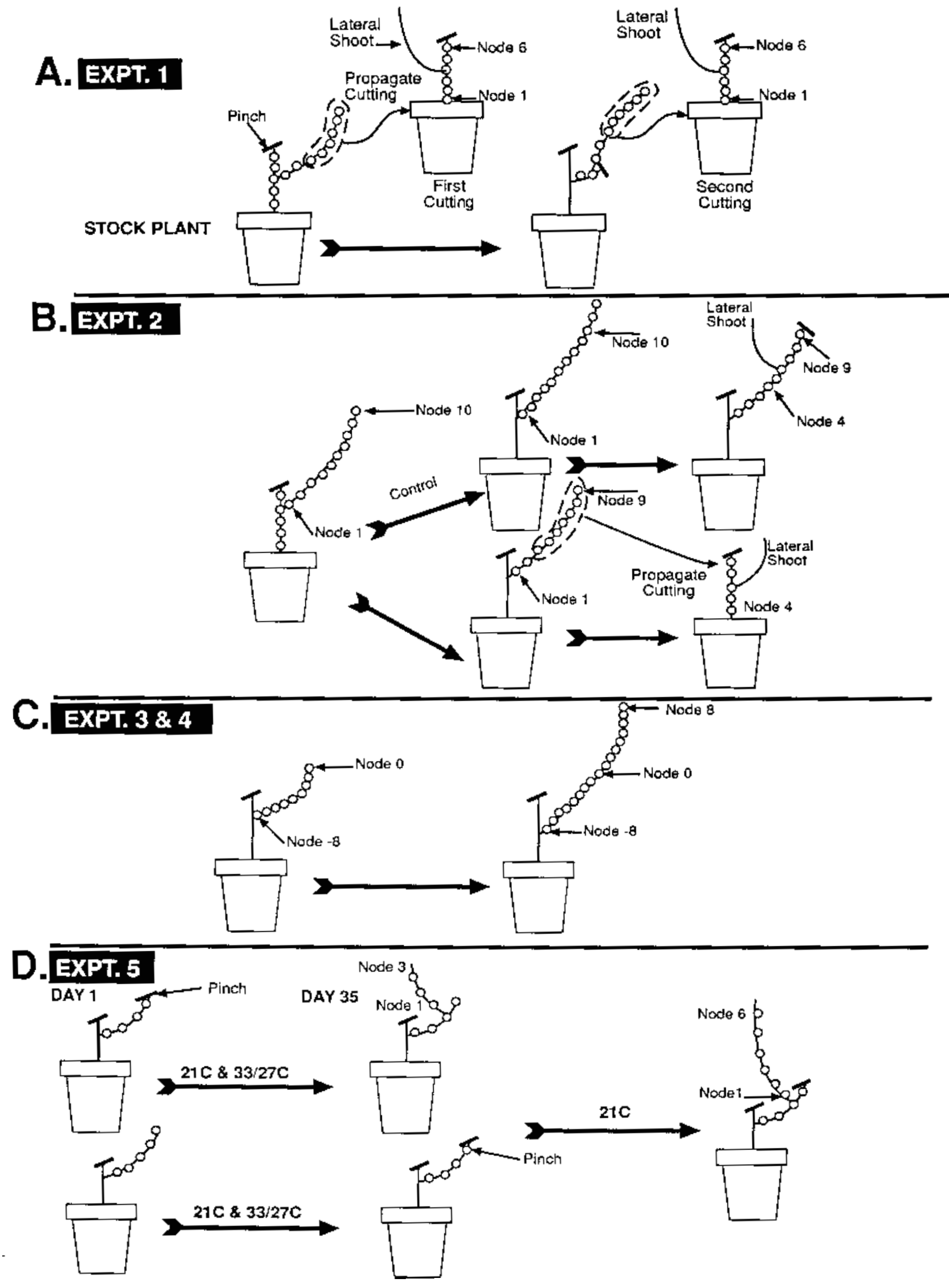

Fig. 1. Diagrams of plant morphology for experiments (A) 1, (B) 2, (C) 3 and 4, and (D) 5. 
$\mathrm{h} \cdot \mathrm{day}^{-1}$. The shoot apex was removed $1 \mathrm{~d}$ after plants were placed into the growth chambers, leaving five nodes on the plants (Fig. 1A). Severe interveinal chlorosis had developed on the leaves by the 12th day after apex removal, especially at 30 and $33{ }^{\circ} \mathrm{C}$. Therefore, the PPF was reduced to $300 \mu \mathrm{mol} \cdot \mathrm{m}^{-2} \cdot \mathrm{s}^{-1}$ in all growth chambers, and the night temperature in the 30 and $33^{\circ} \mathrm{C}$ chambers was reduced to $21^{\circ} \mathrm{C}$.

The number of lateral shoots that developed on each stock plant was recorded. When seven to eight leaves had unfolded, 72 to 104 cuttings per temperature treatment were taken from these lateral shoots, leaving two nodes per lateral. The number of lateral shoots that developed from these two nodes was recorded, and a second group of 28 to 66 cuttings per temperature treatment was removed from the stock plants.

Half of the cuttings removed from the stock plants were shipped via overnight delivery to the Paul Ecke Poinsettia Ranch, and the other half were rooted at the Michigan State Univ. Research Greenhouses, East Lansing, Mich., in oasis strips maintained at 26 ${ }^{\circ} \mathrm{C}$. The rooted cuttings were transplanted 3 to 4 weeks later into $15-\mathrm{cm}$ pots and placed in a greenhouse maintained at $21 \pm 1{ }^{\circ} \mathrm{C}$. These plants were pinched 1 to 2 weeks after being transplanted, and the number of lateral shoots that developed was recorded after 60 d. Experimental results from Michigan- and California-grown plants did not differ statistically (Table 1); therefore, the data presented have been pooled for this paper.

The following grading system was used to describe lateral shoot development from the first and second flush of shoots from the plants grown in Michigan: 1) shoot $>3 \mathrm{~cm}$ long, 2) shoot $<3 \mathrm{~cm}$ long, and 3) no shoot developed.

Experiment 2. One-half of the lateral shoots on Lilo stock plants were removed and propagated (Fig. 1B). The other half of the lateral shoots remained on the stock plant in a $21^{\circ} \mathrm{C}$ greenhouse for the duration of the experiment (i.e., the control group). Axillary buds on nodes 4 through 9 on the cuttings and the control group lateral shoots were rated according to the following scale: 1) welldeveloped bud (bud was green, necrosis was not present, and first leaf was visible), 2) poorly developed bud (necrosis affected all or part of the bud and/or no visible leaf), 3) axillary bud not visible (leaf axil was devoid of an axillary bud). Twenty or more axillary buds were identified in the cuttings and the control group as fitting into each of the three ratings.

The cuttings were propagated, transplanted into pots $15 \mathrm{~cm}$ in diameter $\left(1200 \mathrm{~cm}^{3}\right)$ and placed in a greenhouse maintained at 21 ${ }^{\circ} \mathrm{C}$. The propagated cuttings and the lateral shoots remaining on the control group were pinched above node 9 two weeks after the rooted cuttings were transplanted. Six weeks later, the number of lateral shoots that developed from the rated axillary buds was recorded.

Experiment 3. Thirty-six Red Sails plants (six per treatment) grown under long days at $21^{\circ} \mathrm{C}$ were moved into a high-temperature treatment for $0,2,4,8,16$, or $32 \mathrm{~d}$, then returned to the $21^{\circ} \mathrm{C}$ greenhouse. The high-temperature treatment, hereafter referred to as $33 / 27^{\circ} \mathrm{C}$, consisted of a 16 -h day in which the temperature was set at $30^{\circ} \mathrm{C}$ during the first $3 \mathrm{~h}, 33^{\circ} \mathrm{C}$ for the next $10 \mathrm{~h}$, and $30^{\circ} \mathrm{C}$ for the last $3 \mathrm{~h}$. The greenhouse temperature was $27^{\circ} \mathrm{C}$ for $8 \mathrm{~h}$ during the night. The location of the most recently unfolded leaf (node 0), defined as a leaf longer than $1 \mathrm{~cm}$ and reflexed to at least $45^{\circ}$ from the lateral shoot axis, was recorded at the time of transfer to the $33 / 27^{\circ} \mathrm{C}$ greenhouse (Fig. 1C). Nodes that unfolded after the start of the experiment were assigned positive numbers, 7 being the youngest node. Axillary buds were rated as viable or not viable, according to the scale used in Expt. 2, after $\approx 12$ leaves unfolded on the shoots beyond node 0 . Viable axillary buds were defined by rating 1, while nonviable buds were defined as ratings 2 and 3 . One lateral shoot was examined per plant. Eight nodes were examined per lateral shoot.

Experiment 4 . Thirteen Red Sails plants initially were grown in the $33 / 27^{\circ} \mathrm{C}$ treatment for 1 month and then moved into a $21^{\circ} \mathrm{C}$ greenhouse. The most recently unfolded leaf was recorded at the

Table 1. Significance of $F$ values from general linear model of treatments on the axillary bud viability rating from Expt. 1 .

\begin{tabular}{lrc}
\hline \hline Source & F value & Significance \\
\hline Location (L) & 0.1 & NS \\
Temperature (T) & 142.1 & $* * *$ \\
Node no. (N) & 3.4 & $* *$ \\
Flush (F) & 272.4 & $* * *$ \\
$\mathrm{~L} \times \mathrm{N}$ & 4.7 & $* * *$ \\
$\mathrm{~L} \times \mathrm{T}$ & 2.3 & $\mathrm{NS}$ \\
$\mathrm{T} \times \mathrm{N}$ & 4.5 & $* * *$ \\
$\mathrm{~L} \times \mathrm{F}$ & 0.0 & $\mathrm{NS}$ \\
$\mathrm{T} \times \mathrm{F}$ & 6.3 & $* * *$ \\
$\mathrm{~F} \times \mathrm{N}$ & 1.4 & $\mathrm{NS}$ \\
\hline
\end{tabular}

$\overline{\mathrm{Ns},{ }^{* *},{ }^{* * * *} \text { Nonsignificant or significant at } P<0.01 \text {, or } 0.001 \text {, respectively. }}$

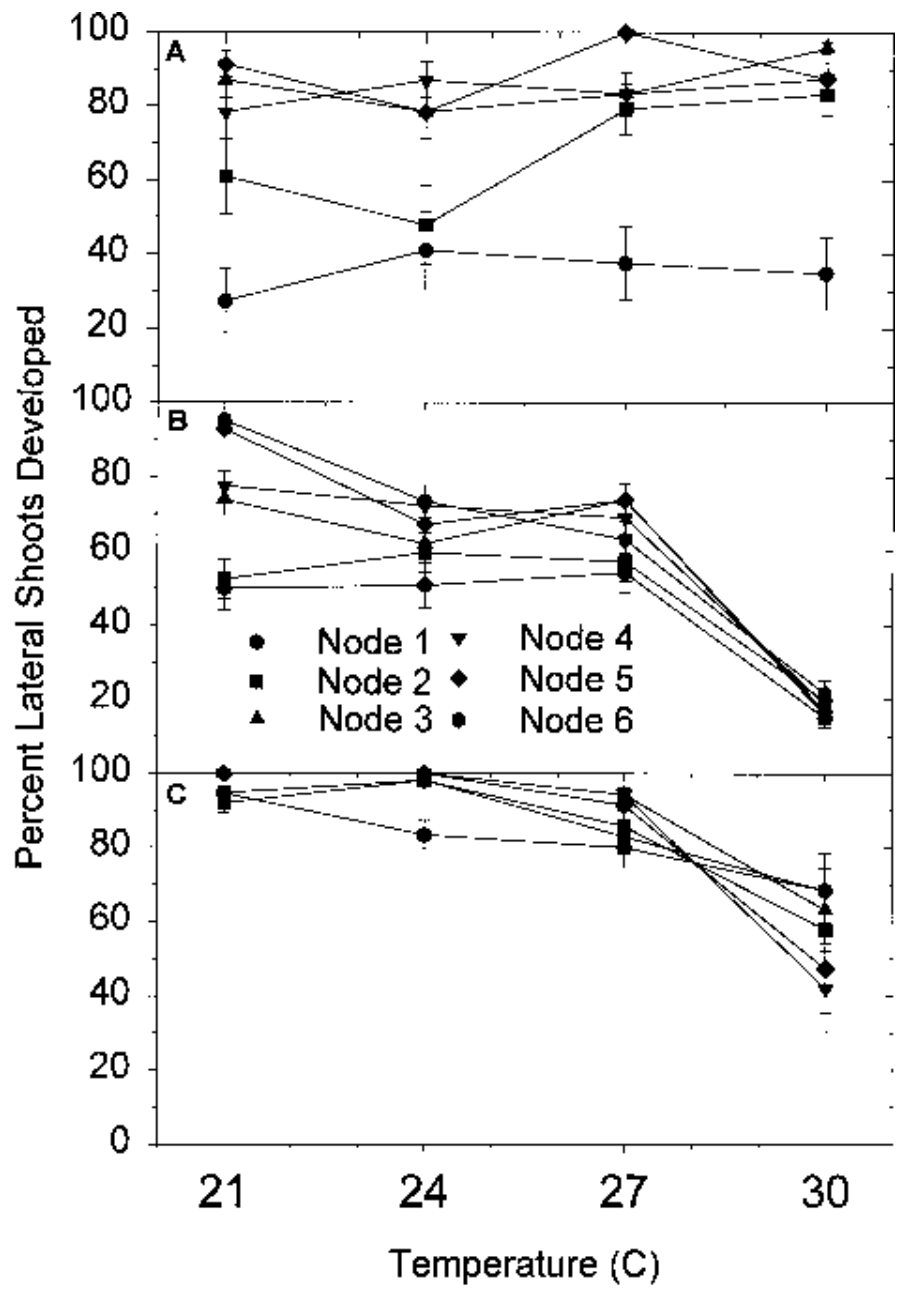

Fig. 2. The effect of temperature and node number on axillary bud development in 'Eckespoint Lilo' poinsettia (Expt. 1). (A) Stock plants after pinching, (B) firstflush cuttings removed from stock plants, and $(\mathbf{C})$ second-flush cuttings removed from stock plants. Rooted cuttings were placed at the indicated temperatures, then pinched. Nodes were numbered from the basal (node 1) to the apical (node 5) part of the shoot. Error bars represent $95 \%$ confidence intervals. 
time of transfer (node 0) (Fig. 1C). The nodes subtended by leaves that unfolded before the start of the experiment were assigned negative numbers, -8 being the oldest node recorded. Those subtended by the eight leaves that unfolded after the start of the experiment were assigned positive numbers, node 8 being the youngest. Axillary buds were rated in the same manner as in Expt. 3 after $\geq 10$ leaves unfolded during the $21^{\circ} \mathrm{C}$ treatment. Two lateral shoots were examined per plant. About 17 nodes were examined per lateral shoot. All visible leaf axils examined possessed a viable axillary bud before the start of the experiment.

Experiment 5. Sixteen Red Sails plants that had been grown for $60 \mathrm{~d}$ under long days at $21{ }^{\circ} \mathrm{C}$ were placed in greenhouses maintained at $21^{\circ} \mathrm{C}$ or $33 / 27^{\circ} \mathrm{C}$. The time of transfer is considered day 1 of the experiment. Four plants in each greenhouse were pinched at the start of the experiment on day 1 , while the remainder of the plants were pinched on day 35 (Fig. 1D). Many more nodes were removed on day 35 than on day 1 so that all laterals would

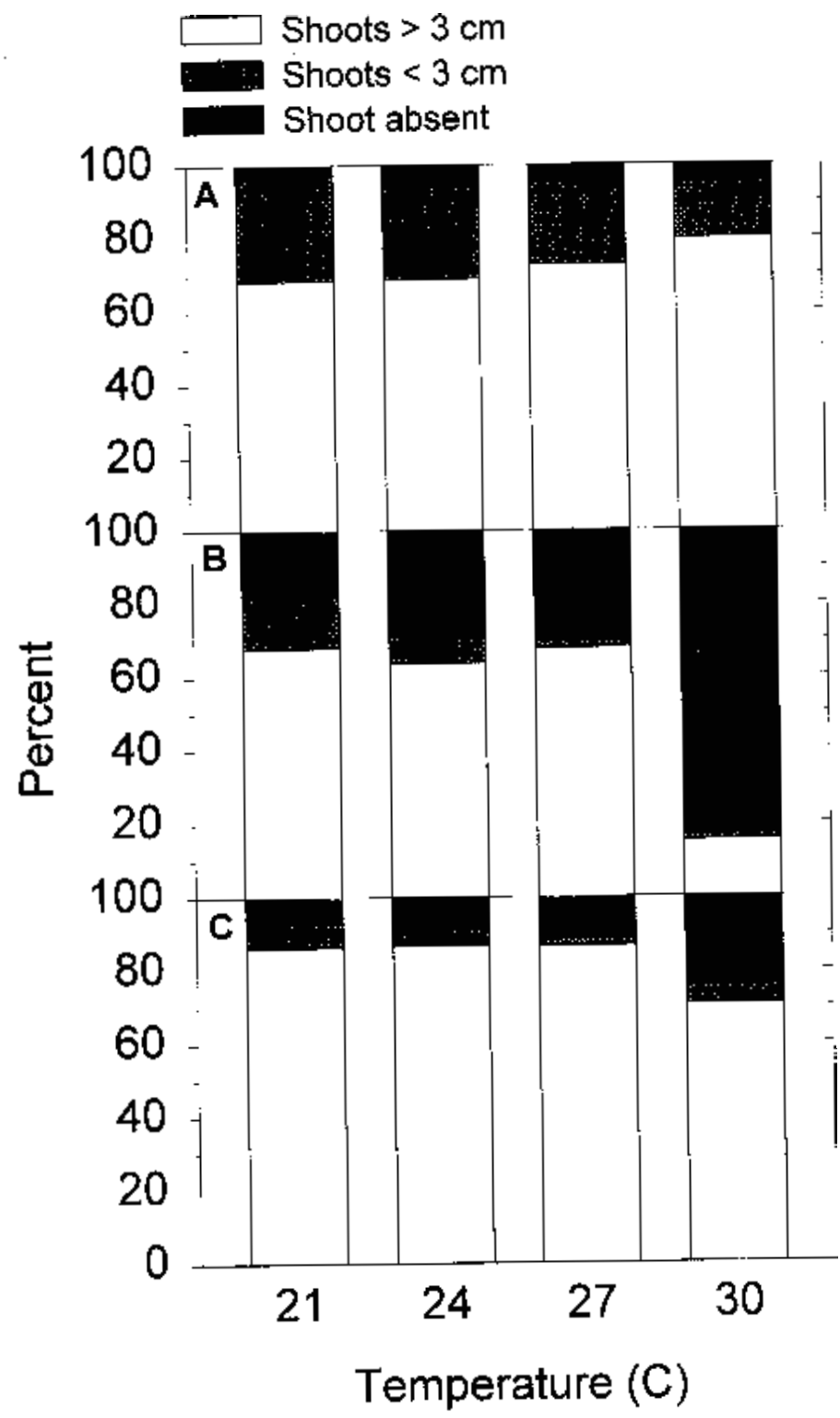

Fig. 3. The effect of temperature on type of axillary shoot developed from 'Eckespoint Lilo' (Expt. 1). (A) Stock plants after pinching, (B) first-flush cuttings removed from stock plants, and (C) second-flush cuttings removed from stock plants. Rooted cuttings were placed at the indicated temperatures then pinched. have the same nodes released from apical dominance. On day 35 , all plants were placed in a greenhouse maintained at $21^{\circ} \mathrm{C}$.

The six basipetal (i.e., lowermost) axillary buds (nodes 1 to 6 ) on the lateral shoots that developed after pinching on days 1 and 35 were rated in the same manner as in Expt. 3 after six or more leaves unfolded on the lateral shoots. Nine lateral shoots were examined per plant. Six nodes were examined per lateral shoot.

\section{Results}

Experiment 1. Although the temperatures at which the shoots developed did not affect the percentage of lateral shoots that developed on the stock plants, nodal position did (Fig. 2A). Thirtyfive percent of the basal nodes (Node 1) and $90 \%$ of the apical nodes (Node 6) produced lateral shoots. The plants grown at $33{ }^{\circ} \mathrm{C}$ developed severe chlorosis and died before data were collected.

The percentage of lateral shoots that developed from the first flush of cuttings removed from the stock plants grown at $30{ }^{\circ} \mathrm{C}$ averaged only $21 \%$, while that of cuttings from stock plants grown at 21,24 , and $27{ }^{\circ} \mathrm{C}$ averaged $74 \%, 65 \%$, and $66 \%$, respectively (Fig. 2B). In general, the basal nodes (nodes 1 and 2) on plants from the 21,24 , and $27^{\circ} \mathrm{C}$ treatments produced fewer shoots than the apical nodes (nodes 5 and 6).

The percentage of lateral shoots that developed on the second flush of cuttings removed from the stock plants was significantly higher than on the first flush (Fig. 2C). As with plants from the first flush of cuttings, axillary bud development in the $30^{\circ} \mathrm{C}$ treatment was significantly lower than that at cooler temperatures. Unlike that of cuttings from the first flush, differences among nodes on the second flush were smaller.

After the initial apex removal on the stock plants, $20 \%$ to $30 \%$ of the nodes produced no shoots or shoots $<3 \mathrm{~cm}$ long (Fig. 3A). Less than $7 \%$ of the axillary buds failed to produce any shoot, regardless of temperature. In contrast, on the first flush of cuttings (Fig. 3B), 54\% of the axillary buds failed to develop into shoots $>3$ $\mathrm{cm}$ long. From the stock plants grown at $30{ }^{\circ} \mathrm{C}, 83 \%$ of the nodes on the first flush of cuttings (Fig. 3B) and $25 \%$ of those on the second produced no lateral shoots (Fig. 3C).

Experiment 2. The axillary bud rating at the time of cutting removal was a good indicator of lateral shoot development after propagation and pinching. Of the buds rated as viable before cutting removal, $83 \%$ developed a lateral shoot after propagation. Of the buds that were partially necrotic or had no visible leaf, $38 \%$ developed a lateral shoot after propagation. Of the nodes on the control group, $45 \%, 5 \%$, and $0 \%$ of the nodes on the control group developed lateral shoots when the initial nodal rating was 1,2 , or 3 , respectively.

Experiment 3 . Transferring plants from $21^{\circ} \mathrm{C}$ to $33 / 27^{\circ} \mathrm{C}$ for 16 or $32 \mathrm{~d}$ reduced the percentage of viable axillary buds on nodes 3 through 7 (Table 2); holding plants at $33 / 27^{\circ} \mathrm{C}$ for $8 \mathrm{~d}$ or fewer did not reduce viable axillary bud count. The first two nodes that developed after the initial transfer were not influenced by the 33/ $27^{\circ} \mathrm{C}$ treatment, while node 4 was the first node to be completely inhibited in the 32-d treatment. All buds in the axils of leaves that unfolded before the initial transfer were viable (data not shown).

Experiment 4. Transferring plants from $33 / 27{ }^{\circ} \mathrm{C}$ to $21{ }^{\circ} \mathrm{C}$ increased the percentage of viable axillary buds (Fig. 4). Nodes 8 to -4 were not influenced by the temperature change, while nodes -3 to 0 (i.e., the four youngest nodes whose leaves unfolded before transfer to $21^{\circ} \mathrm{C}$ ) displayed an increase in bud viability. Of the nodes developed after being transferred to $21{ }^{\circ} \mathrm{C}, 62 \%$ to $95 \%$ yielded viable axillary buds.

Experiment 5. Plants grown at $21^{\circ} \mathrm{C}$ and pinched on day 1 or 35 
produce $89 \%$ or $83 \%$ viable axillary buds, respectively, on the lateral shoot that emerged after pinching (Table 3 ). Plants placed into the $33 / 27^{\circ} \mathrm{C}$ treatment for 35 $\mathrm{d}$ and then pinched produced $75.8 \%$ viable axillary buds on the lateral shoot that emerged after pinching. However, plants pinched on day 1 and placed into the 33/27 ${ }^{\circ} \mathrm{C}$ treatment for 35 days produced only $22.2 \%$ viable buds on the lateral shoots that emerged after pinching.

\section{Discussion}

Results presented in this paper support the hypothesis that high temperatures inhibit axillary bud development in Lilo and Red Sails poinsettia, resulting in poor lateral shoot development. Visual observations of poinsettia leaf axils indicated that, at times, the axil was completely devoid of an axillary bud, while at other times the "bud" consisted of a mass of undifferentiated cells. High temperatures $\left(>27{ }^{\circ} \mathrm{C}\right)$ interrupted or prevented axillary bud initiation, development, or both. Blind leaf axils (rating 3 ) did not produce lateral shoots, and poorly developed (rating 2) axillary buds did not consistently produce lateral shoots.

Buds developing in the axils of folded leaves were sensitive to high temperatures, but once leaf unfolding occurred, they were no longer sensitive. Viable axillary buds released from apical dominance developed into lateral shoots regardless of temperature. Consequently, one cause of poor branching in poinsettias was exposure of plants to temperatures $>27^{\circ} \mathrm{C}$. If plants pinched shortly after propagation fail to branch properly, high temperatures probably occurred during stock plant production. However, other environmental problems, such as drought stress or high media salinity, should also be considered.

Temperatures during propagation often were $>27^{\circ} \mathrm{C}$; however, our data show that viable axillary buds will produce a lateral shoot regardless of temperature (Expt. 1) and propagation process (Expt. 2 ). In other words, viable axillary buds do not degrade during propagation. The percentage of lateral shoots that developed from viable axillary buds on the control group in Expt. 2 was lower than that from the viable buds on the cuttings due to stronger apical dominance of the apical nodes of the control group. The reason for this result is that when a rooted cutting is pinched, typically all five remaining nodes will be released from apical dominance; however, when a lateral shoot is pinched on a multi-stemmed stock plant (the control), typically only the top two to four nodes may be released from apical dominance.

Viable quiescent axillary buds exposed to high temperatures will produce a lateral shoot that also has viable axillary buds if cool temperatures are provided after pinching (Expt. 5). However, lateral shoots that emerge in a high-temperature environment will
1. Healthy Bud 2. Necrotic Bud 3. "Blind" Axil

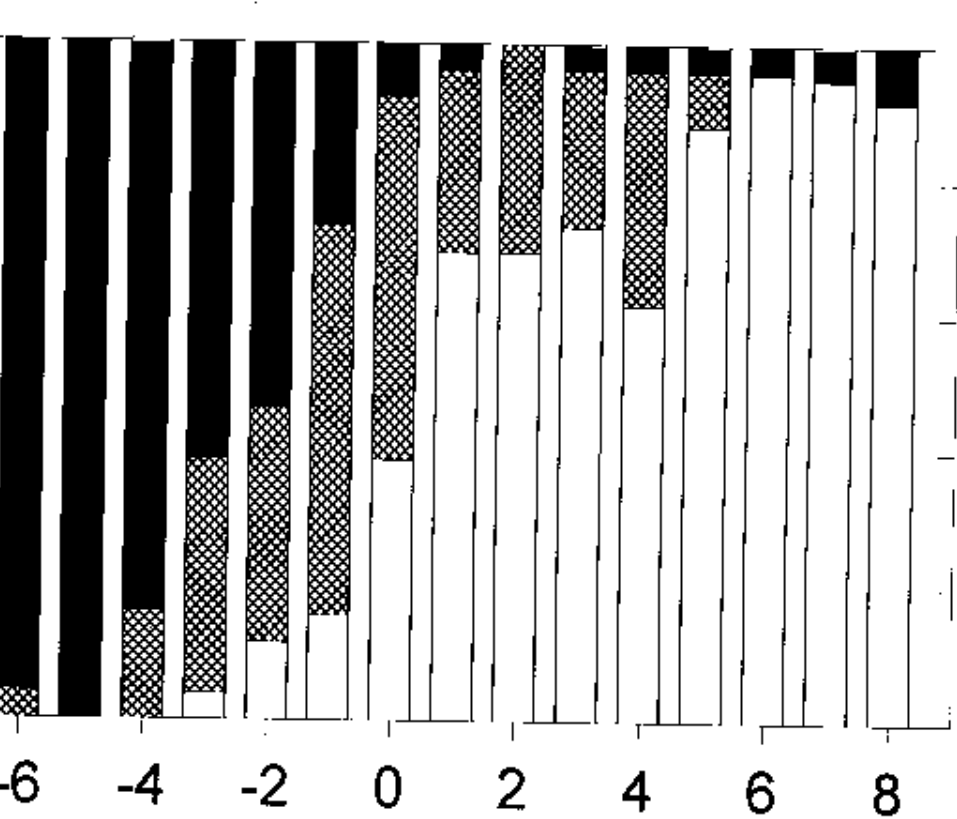

\section{Relative Node Number}

Fig. 4. Effect of high temperature on axillary bud development of 'Eckespoint Red Sails' poinsettias initially grown at 33/ $27^{\circ} \mathrm{C}$ and then transferred to $21^{\circ} \mathrm{C}$. Node 0 indicates the most recently unfolded leaf at the time of transfer. Negative numbers indicate nodes whose leaves unfolded before transfer, while positive numbers indicate nodes whose leaves unfolded after transfer. (Node -8 was the oldest; node +8 , the youngest.) (Expt. 4)

produce a high percentage of nonviable axillary buds. Thus, high temperatures that may occur during propagation will not influence branching of a plant pinched 2 to 3 weeks after the propagation phase ends. Also, high propagation temperatures will not affect axillary bud development on the lateral shoots that emerge after pinching. High temperatures affect only axillary buds that are initiating and developing in actively growing shoot tips.

The maximum percentage of axillary bud or lateral shoot development varied among experiments. For example, in Expt. 1, $\approx 90 \%$ of the axillary buds from the second flush of cuttings developed lateral shoots, while only $70 \%$ of the axillary buds from the first flush of cuttings developed lateral shoots. The reason for the variability is not clear, although it possibly is due to an interaction with some other environmental factor. For example, axillary bud development may have been influenced by PPF, since the first flush of cuttings was exposed to $600 \mu \mathrm{mol} \cdot \mathrm{m}^{-2} \cdot \mathrm{s}^{-1}$ for 2 weeks, while the second flush of cuttings was only exposed to $300 \mu \mathrm{mol} \cdot \mathrm{m}^{-2} \cdot \mathrm{s}^{-1}$. The higher PPF may have increased plant temperatures, especially considering that fluorescent and incandescent lamps were used without a thermal energy filter (Faust and Heins, 1996).

Transferring stock plants from $33 / 27$ to $21^{\circ} \mathrm{C}$ improved axillary bud development. Of the axillary buds from nodes that developed after transfer, $70 \%$ were viable. When stock plants were transferred from $21^{\circ} \mathrm{C}$ to $33 / 27^{\circ} \mathrm{C}$ for $32 \mathrm{~d}$, three leaves unfolded after the transfer before bud development was affected. Perhaps the negative effect of high temperatures during early stages of bud development can be overcome by cooler temperatures later in 
development, and later stages of bud development are less sensitive to high temperatures.

Sixteen consecutive days at $33 / 27^{\circ} \mathrm{C}$ were required to inhibit bud development of Red Sails in Expt. 4; however, the response of poinsettias to high temperature may be quantitative. In other words, as temperature increases above the critical $27^{\circ} \mathrm{C}$, fewer days may be required for inhibition. Likewise, different poinsettia cultivars may exhibit different degrees of high-temperature sensitivity. Our results indicate that Lilo would require fewer days at high temperatures than Red Sails (i.e., the former is more sensitive to high temperatures). In separate experiments in which plants were grown continuously at $33 / 27^{\circ} \mathrm{C}$, 'Eckespoint Freedom' also displayed a reduction in the number of lateral shoots developed; however, 'Eckespoint Freedom' is considerably less sensitive to high temperatures than Red Sails.

In summary, poor branching appears to be a result of at least two factors. First, apical dominance results in a decreased percentage of lateral shoots developing on nodes positioned lower on the stem. Second, incomplete development of axillary buds prohibits lateral shoot development after pinching. Poor axillary bud development is the major problem during commercial production of Lilo and Red Sails when greenhouse temperatures cannot be adequately controlled.

Poinsettias regenerated following heat treatment or suspension culture branch poorly. Although axillary buds on these plants are well-developed (personal communication, Kirsten Rasmussen, Aaslev, Denmark), only one or two shoots develop after apex removal (personal communication, Walter Preil, Ahrensburg, Germany), indicating that these plants possess extremely strong correlative inhibition. Considerable research has been undertaken to identify the factor that promotes branching of poinsettia; however, even if the branching agent proposed by Dole and Wilkins (1994) is identified, this solution may explain only the apical dominance problem, not the axillary bud development problem.

The goal for the commercial poinsettia propagator is to produce viable axillary buds on the stock plants, which can be accomplished by maintaining temperatures at $\leq 27{ }^{\circ} \mathrm{C}$ during stock plant production of Lilo and Red Sails. Since temperatures are often $\geq 27$ ${ }^{\circ} \mathrm{C}$, increased shading and misting plants with water may help reduce temperature. Bud viability on stock plants may be monitored before harvesting cuttings to prevent propagation of cuttings that will not produce well-branched plants. The soft-pinch leaf

Table 2. Effects of the duration of a high day-temperature treatment on the axillary bud development of 'Eckespoint Red Sails' poinsettias in the leaf axils of nodes 0 to 7 . Node 0 refers to the node with the most recently unfolded leaf at the time of transfer, while nodes 1 through 7 represent the nodes that developed after the start of the experiment (Expt. 3).

\begin{tabular}{|c|c|c|c|c|c|c|c|c|}
\hline \multirow{3}{*}{$\begin{array}{l}\text { Days at } \\
33 / 27^{\circ} \mathrm{C}\end{array}$} & \multicolumn{8}{|c|}{ Nodes developing lateral shoots $(\%)$} \\
\hline & \multicolumn{8}{|c|}{ Node (no.) } \\
\hline & 0 & 1 & 2 & 3 & 4 & 5 & 6 & 7 \\
\hline$\overline{0}$ & 100 & 100 & 100 & 100 & 100 & 100 & 100 & 100 \\
\hline 2 & 100 & 100 & 100 & 100 & 100 & 100 & 100 & 100 \\
\hline 4 & 100 & 100 & 100 & 100 & 100 & 100 & 100 & 100 \\
\hline 8 & 100 & 100 & 100 & 100 & 100 & 83 & 100 & 100 \\
\hline 16 & 83 & 100 & 83 & 83 & 33 & 33 & 67 & 83 \\
\hline 32 & 100 & 100 & 100 & 83 & 0 & 0 & 0 & 0 \\
\hline Source & \multicolumn{6}{|c|}{ F value } & \multicolumn{2}{|c|}{ Significance } \\
\hline$\overline{\text { Days (D) }}$ & \multicolumn{6}{|c|}{93.6} & \multicolumn{2}{|c|}{$* * *$} \\
\hline Node no. $(\mathrm{N})$ & \multicolumn{6}{|c|}{14.0} & \multicolumn{2}{|c|}{$* * *$} \\
\hline $\mathrm{D} \times \mathrm{N}$ & \multicolumn{6}{|c|}{11.6} & \multicolumn{2}{|c|}{$* * *$} \\
\hline
\end{tabular}

Significant at $P<0.001$.
Table 3. Effect of temperature and pinch date on the axillary bud viability of 'Eckespoint Red Sails' (Expt. 5). The temperature treatments were delivered during the first 35 days of the experiment. All plants were grown at $21^{\circ} \mathrm{C}$ after day 35 .

\begin{tabular}{|c|c|c|c|c|c|c|c|}
\hline \multirow{3}{*}{$\begin{array}{l}\text { Temp } \\
\left({ }^{\circ} \mathrm{C}\right)\end{array}$} & \multirow{3}{*}{$\begin{array}{c}\text { Pinch } \\
\text { date }\end{array}$} & \multicolumn{6}{|c|}{ Axillary bud viability (\%) } \\
\hline & & \multicolumn{6}{|c|}{ Node no. } \\
\hline & & 1 & 2 & 3 & 4 & 5 & 6 \\
\hline \multirow[t]{2}{*}{$\overline{21}$} & 1 & 93.2 & 68.1 & 80.7 & 94.3 & 100 & 100 \\
\hline & 35 & 80.2 & 57.8 & 73.6 & 91.3 & 95.9 & 100 \\
\hline \multirow[t]{2}{*}{$33 / 27$} & 1 & 57.0 & 15.0 & 4.2 & 11.5 & 31.0 & 14.3 \\
\hline & 35 & 89.7 & 58.6 & 78.1 & 71.1 & 82.3 & 75.0 \\
\hline \multicolumn{2}{|c|}{ Source } & \multicolumn{4}{|c|}{$\mathrm{F}$ value } & \multicolumn{2}{|c|}{ Significance } \\
\hline \multicolumn{2}{|c|}{$\overline{\text { Temperature }(\mathrm{T})}$} & \multicolumn{4}{|c|}{85.0} & \multicolumn{2}{|c|}{$* * *$} \\
\hline \multicolumn{2}{|c|}{ Pinch date $(\mathrm{P})$} & \multicolumn{4}{|c|}{210.4} & \multicolumn{2}{|c|}{$* * *$} \\
\hline \multicolumn{2}{|c|}{ Node $(\mathrm{N})$} & \multicolumn{4}{|c|}{33.7} & \multicolumn{2}{|c|}{$* * *$} \\
\hline \multicolumn{2}{|c|}{$\mathrm{P} \times \mathrm{T}$} & \multicolumn{4}{|c|}{135.9} & \multicolumn{2}{|c|}{$* * *$} \\
\hline \multicolumn{2}{|l|}{$\mathrm{P} \times \mathrm{N}$} & \multicolumn{4}{|c|}{11.9} & \multicolumn{2}{|c|}{$* * *$} \\
\hline \multicolumn{2}{|l|}{$\mathrm{T} \times \mathrm{N}$} & \multicolumn{4}{|c|}{4.8} & \multicolumn{2}{|c|}{$* * *$} \\
\hline \multicolumn{2}{|c|}{$\mathrm{P} \times \mathrm{T} \times \mathrm{N}$} & \multicolumn{4}{|c|}{2.4} & \multicolumn{2}{|c|}{$*$} \\
\hline
\end{tabular}

removal technique (Berghage et al., 1989) can be used to improve branching by providing more nodes and, thus, more potential lateral shoots (Hughes et al., 1991) on shoots with improperly differentiated basipetal buds. If temperature control during stock plant production is not possible, then the problem of poor lateral branching in poinsettias must be resolved by selecting cultivars not sensitive to, or only slightly sensitive to, high-temperatureinduced axillary bud inhibition. If viable axillary buds are present but poor branching still occurs, other causes may need to be considered, such as drought stress, high media salinity, poor root development, and root diseases.

\section{Literature Cited}

Berghage, R.D., R.D. Heins, M. Karlsson., J.E. Erwin, and W. Carlson. 1989. Pinching technique influences lateral shoot development in poinsettia. J. Amer. Soc. Hort. Sci. 114:909-914.

Boonprakob, U., D.H. Byrne, R.E. Rouse, and D.M.J. Mueller. 1993. Anatomy of blind nodes in peach. HortScience 28:568. (Abstr.)

Dole, J.M. and H.F. Wilkins. 1991. Vegetative and reproductive characteristics of poinsettia altered by a graft-transmissible agent. J. Amer. Soc. Hort. Sci. 116:307-311.

Dole, J.M. and H.F. Wilkins. 1992. In vivo characterization of a grafttransmissible free-branching agent in poinsettia. J. Amer. Soc. Hort. Sci. 117:972-975.

Dole, J.M. and H.F. Wilkins. 1994. Graft-transmissible branching agent, p. 45-48. In: E. Stromme (ed.). The scientific basis of poinsettia production. Agr. Univ. Norway, Aas.

Dole, J.M., H.F. Wilkins, and S.L. Desborough. 1993. Investigation on the nature of a graft-transmissible agent in poinsettia. Can. J. Bot. 71:1097-1101.

Ecke, P., Jr., O.A. Matkin, and D.E. Hartley. 1990. The poinsettia manual. 3rd ed. Paul Ecke Poinsettias, Encinitas, Calif.

Faust, J.E. and R.D. Heins. 1992. High night temperatures do not cause 
poor lateral branching of chrysanthemum. HortScience 27:981-982.

Faust, J.E. and R.D. Heins. 1993. Stop poor poinsettia branching. Greenhouse Grower 11:66-70.

Faust, J.E. and R.D. Heins. 1996. Quantifying the influence of highpressure sodium lighting on shoot-tip temperature. Acta Hort. (In press.) Hughes, J., W. Brown, G. Murphy, J. Tsujita, and T. Blom. 1991. The influence of pinching on poinsettia growth. Greenhouse Canada January:21-23.

Preil, W. 1994. The study of chimerism, elimination of virus, and the induction of mutagenesis in poinsettia, p. 57-63. In: E. Stromme (ed.).
The scientific basis of poinsettia production. Agr. Univ. Norway, Aas. Preil, W. and M. Engelhart. 1982. In vitro separation of chimeras by suspension cultures of Euphorbia pulcherrima Willd. Gartenbauwissenschaft 47:241-244.

Schoelhorn, R.K., J.E. Barrett, and T.A. Nell. 1995. Changes in chrysanthemum meristem and lateral bud development at elevated temperatures. HortScience 30:760. (Abstr.)

Stimart, D.P. 1983. Promotion and inhibition of branching in poinsettia in grafts between self-branching and nonbranching cultivars. J. Amer. Soc. Hort. Sci. 108:419-422. 